\title{
Possible reasons for differences in residual feed intake: An overview
}

\author{
J. Hendriks ${ }^{1,2}$, M.M. Scholtz ${ }^{1,2 \#}$ \& F.W.C. Neser ${ }^{2}$ \\ ${ }^{1}$ ARC-Animal Production Institute, Private Bag X2, Irene, 0062, South Africa \\ ${ }^{2}$ University of the Free State, PO Box 339, Bloemfontein, 9300, South Africa
}

(Received 25 September 2012; Accepted 19 November 2012; First published online 5 September 2013)

\author{
Copyright resides with the authors in terms of the Creative Commons Attribution 2.5 South African Licence. See: \\ http://creativecommons.org/licenses/by/2.5/za/Condition of use: The user may copy, distribute, transmit and adapt the work, but must \\ recognise the authors and the South African Journal of Animal Science
}

\begin{abstract}
Selection for residual feed intake (RFI) as a trait to improve production efficiency was proposed as early as 1963. A low RFI value indicates a more efficient animal and heritability estimates of between 0.28 and 0.58 have been reported for RFI in the literature. It is also reported that a $13.38 \mathrm{~g} / \mathrm{d}$ reduction in methane emission was associated with a $1 \mathrm{~kg} / \mathrm{d}$ reduction in the Estimated Breeding Value (EBV) for RFI, with lowRFI steers emitting 25\% less methane daily. The difference in methane production in high and low RFI animals cannot be explained by the difference in feed intake alone. Possible reasons could be digestion of feed, protein turnover and overall tissue metabolism (mitochondrial function, body composition, Insulin Growth Factor-I (IGF-I) and cortisol levels), activity, thermoregulation and growth. Low-RFI animals tend to digest feed better than high-RFI animals, and as intake increases there is a tendency for digestion to decrease. The correlation between RFI and dry matter (DM) digestibility has been determined to be $r=-0.33$. A positive correlation exists between metabolisable energy for maintenance (ME) and RFI, as well as between ME and protein turnover. Thus protein secretion in low-RFI animals are the same as high-RFI animals, but the breakdown of protein in low-RFI animals is less. Clear differences can be observed in heat production, with low-RFI animals producing up to $21 \%$ less heat than high-RFI animals. Selection for lowRFI animals may thus reduce the carbon footprint of beef cattle.
\end{abstract}

Keywords: Body composition, production efficiency, carbon footprint, protein turnover, selection indices, methane emission

"Corresponding author: GScholtz@arc.agric.za

\section{Introduction}

Common measures of efficiency is feed conversion ratio (feed consumed/weight gain) or feed efficiency (weight gain/feed consumed). However, efficiency is highly associated with growth rate, leading to an increase in mature size, which in turn increases the maintenance cost of the breeding herd. It has been shown that residual feed intake (RFI) is independent from growth rate and mature weight, leading to the reduction of feed intake without affecting growth performance or mature size. RFI is defined as the difference between the actual feed intake and that predicted from the requirements for maintenance and growth (Koch et al., 1963).

The selection for reduced RFI will reduce feed costs and thus improve beef production profitability. It will also lead to less methane emissions, since a positive correlation exists between RFI and methane production, thus reducing the carbon footprint of beef cattle (Nkrumah et al., 2006). The objective of this paper is to give an overview of the reasons and mechanisms associated with differences in RFI, as well as the different contributions to the variation in RFI. 


\section{Discussion}

The difference in RFI and methane production in high- and low -RFI animals cannot be explained by the difference in feed intake alone. Possible other reasons could be digestion of feed, protein turnover, overall tissue metabolism, activity, thermoregulation and growth. Table 1 gives an overview of possible reasons and mechanisms for differences in residual feed intake.

Table 1 A summary of possible reasons for differences in residual feed intake in beef cattle

\begin{tabular}{|c|c|c|}
\hline Trait & Description & Correlation with RFI \\
\hline $\begin{array}{l}\text { Metabolisable } \\
\text { energy } \\
\text { requirements }\end{array}$ & $\begin{array}{l}\text { Less energy is used in the physiological processes for maintenance } \\
\text { requirements for low-RFI animals (Castro Bulle et al., 2006). }\end{array}$ & $0.421(P<0.10)$ \\
\hline $\begin{array}{l}\text { Body } \\
\text { composition } \\
\text { (Fat gain) }\end{array}$ & $\begin{array}{l}\text { Low-RFI animals have less whole body chemical-fat and more whole } \\
\text { body chemical-protein; thus, there is a positive correlation between } \\
\text { RFI and fat gain. Visceral organ size is a big contributing factor to } \\
\text { heat production and energy use, with low-RFI animals having smaller } \\
\text { visceral organs (Herd \& Arthur, 2008). }\end{array}$ & $0.375(P<0.10)$ \\
\hline $\begin{array}{l}\text { Dry matter intake } \\
\text { (DMI) }\end{array}$ & $\begin{array}{l}\text { Feed cost is one of the largest expenses in beef operations, and it was } \\
\text { found that high-RFI bulls consumed } 17 \% \text { - } 18 \% \text { more feed than low- } \\
\text { RFI bulls (Ferrel \& Jenkins, 1998; Castro Bulle et al., 2006; } \\
\text { Lancaster et al., 2009). }\end{array}$ & $0.44(P<0.001)$ \\
\hline Digestibility & $\begin{array}{l}\text { Digestibility may be influenced by variation in factors such as } \\
\text { feeding behaviour, ruminal retention time, mechanism of digestion } \\
\text { and absorption. Low-RFI animals have better dry matter } \\
\text { digestibilities than high-RFI animals (Oddy \& Herd, 2001). }\end{array}$ & -0.33 to -0.44 \\
\hline $\begin{array}{l}\text { Heat Production } \\
\text { (HP) }\end{array}$ & $\begin{array}{l}\text { A difference of up to } 21 \% \text { in HP exists between low- and high-RFI } \\
\text { animals. Visceral organs account for } 40 \%-50 \% \text { of HP. High-RFI } \\
\text { animals have higher levels of HP and also greater visceral organ size } \\
\text { (Basarab et al., 2003; Nkrumah et al., 2006). }\end{array}$ & 0.68 \\
\hline Activity & $\begin{array}{l}\text { It was determined that about } 10 \% \text { of the RFI variation can be } \\
\text { explained by physical activity in growing calves. Feeding duration of } \\
\text { low-RFI bulls is up to } 25 \text { min/day less than high-RFI bulls } \\
\text { (Richardson et al., 2004; Lancaster et al., 2005). }\end{array}$ & 0.32 \\
\hline $\begin{array}{l}\text { Methane } \\
\text { production }\end{array}$ & $\begin{array}{l}\text { Low-RFI animals produce } 28 \% \text { less methane than high-RFI animals } \\
\text { leading to approximately } 16100 \text { L less methane per year. A positive } \\
\text { association also exists between energy intake and methane } \\
\text { production (Nkrumah et al., 2006). }\end{array}$ & 0.44 \\
\hline Protein turnover & $\begin{array}{l}\text { Animals with greater maintenance requirements have greater protein } \\
\text { turnover. Low- and high-RFI animals accrete body tissue at the same } \\
\text { rate but low RFI animals may have reduced protein turnover } \\
\text { (Richardson \& Herd, 2004). }\end{array}$ & \\
\hline
\end{tabular}

Nkrumah et al. (2006) reported a 28\% difference in methane production between low-RFI and highRFI animals, which has the effect that low-RFI animals produces about $16100 \mathrm{~L} /$ year less methane than high-RFI animals. It was also found that there is a positive correlation between RFI and daily methane production and energy lost as methane $(r=0.44)$. Hegarty et al. (2007) found a $13.38 \mathrm{~g} / \mathrm{d}$ reduction in methane emission was associated with a $1 \mathrm{~kg} / \mathrm{d}$ reduction in the EBV for RFI. A positive association exists between energy intake and methane production, with the higher intake providing more substrate for ruminal fermentation and thus there is more hydrogen available for the formation of methanogens. Thus, selecting 
livestock with lower feed intake can be used as means to select for animals with less methane emissions $\left(h^{2}=0.42\right)$. Hegarty et al. (2007) found that low-RFI animals emitted $25 \%$ less methane and ate $41 \%$ less than high-RFI steers, with low-RFI steers having a 24\% lower methane cost per unit ADG.

Mitochondrial function is an important factor in the efficiency of net feed intake in livestock (Naik, 2007) and is influenced significantly by genetics and diets (Bottje et al., 2002). About 90\% of cellular energy is produced by mitochondria in metabolically active cells like the liver, kidney, muscle and brain cells (Ojano-Dirain et al., 2007). Energy production takes place in the mitochondria and cellular ATP is produced (Kolath et al., 2006). Electron leakage may take place due to inefficiency of mitochondria, with the result that $2 \%-4 \%$ of oxygen consumed by mitochondria are not completely reduced to water, but are reduced to reactive oxygen species (ROS) which are very destructive (Boveris \& Chance, 1973). These reactive oxygen species may cause damage to nucleic acids, lipids and proteins through oxidation and may also damage the mitochondria themselves. This may cause the mitochondria to function less efficiently (Nelson \& Cox, 2008). Bottje et al. (2002) found that the mitochondria of low feed efficient chickens produced the highest levels of ROS, and in another study it was found that electron leakage in the mitochondria of low feed efficient chickens was higher than in high feed efficient chickens.

There are many factors and mechanisms that contribute to variation in RFI between animals. The contributions from the different factors and mechanisms are illustrated in Figure 1 (from Richardson \& Herd, 2004). From Figure 1 it can be seen that protein turnover, tissue metabolism and stress explain $37 \%$ of the variation in RFI, whereas feeding patterns only explain $2 \%$ of the variation.

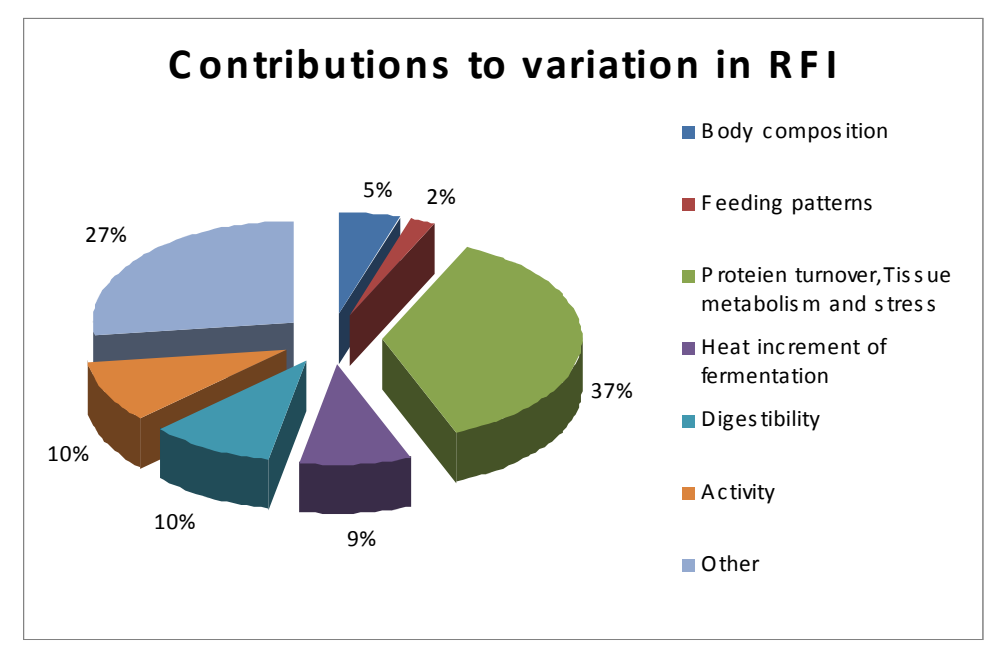

Figure 1 Factors that contribute to variation in RFI between animals (from Richardson \& Herd, 2004).

\section{Conclusion}

In order to calculate RFI it is necessary to measure individual feed intake of animals. The cost and difficulty in measuring RFI makes the trait a strong candidate for marker assisted selection. The selection for lower RFI values will reduce feed costs, and thus improve beef production profitability which will reduce the carbon footprint of beef cattle. Studies have also shown that low-RFI cattle produce less methane.

It has been shown that RFI is independent from growth rate and mature weight. Selection for RFI will thus lead to the reduction of feed intake without affecting growth performance or mature size. It is therefore, important to recognize that the most desirable animals, with respect to efficiency, may be outliers in respect of other traits, e.g. growth rate. Breeders are advised to make selection decisions based on carefully constructed breeding objectives and selection indexes and not on single traits.

\section{Acknowledgement}

This work is based on research supported in part by Red Meat Research and Development South Africa and the National Research Foundation of South Africa, under grant UID 75123. The grantholder acknowledges that opinions, findings and conclusions or recommendations expressed in any publication 
generated by the NRF supported research are that of the authors and that the NRF accepts no liability whatsoever in this regard.

\section{References}

Basarab, J.A., Price, M.A., Aalhus, J.L, Okine, E.K., Snelling, W.M. \& Lyle, K.L., 2003. Residual feed intake and body composition in young growing cattle. Can. J. Anim. Sci. 83, 189-204.

Bottje, W., Tang, Z.X., Iqbal, M., Cawthon, D., Okimoto, R., Wing, T. \& Cooper, M., 2002. Association of mitochondrial function with feed efficiency within a single genetic line of male broilers. Poult. Sci. 81, 546-555.

Boveris, A. \& Chance, B., 1973. The mitochondrial generation of hydrogen peroxide: General properties and effect of hyperbaric oxygen. Biochem. J. 134, 707-716.

Castro Bulle, F.C.P., Paulino, P.V., Sanches, A.C. \& Sainz, R.D., 2006. Growth, carcass quality, and protein and energy metabolism in beef cattle with different growth potentials and residual feed intakes. J. Anim. Sci. 85, 928-936.

Ferrell, C.L. \& Jenkins, T.G., 1998. Body composition and energy utilization by steers of diverse genotypes fed a high-concentrate diet during the finishing period: I. Angus, Belgian Blue, Hereford and Piedmontese sires. J. Anim. Sci. 76, 637-646.

Hegarty, R.S., Goopy, J.P., Herd, R M. \& McCorkell, B., 2007. Cattle selected for lower residual feed intake have reduced daily methane production. J. Anim. Sci. 85, 1479-1486.

Herd, R.M. \& Arthur, P.F., 2008. Physiological basis for residual feed intake. J. Anim. Sci. 87, 64-71.

Koch, R.M., Swiger, L.A., Chambers, D. \& Gregory, K.E., 1963. Efficiency of feed use in beef cattle. J. Anim. Sci. 22, 486-494.

Kolath, W.H., Kerley, M.S., Golden, J.W. \& Keisler, D.H., 2006. The relationship between mitochondrial function and residual feed intake in Angus steers. J. Anim. Sci. 84, 861-865.

Lancaster, P.A., Carstens, G.E., Crews Jr., D.H., Welsh Jr., T.H., Forbes, T.D.A., Forrest, D.W., Tedeschi, L.O., Randel, R.D. \& Rouquette, F.M., 2009. Phenotypic and genetic relationships of residual feed intake with performance and ultrasound carcass traits in Brangus heifers. J. Anim. Sci. 87, 3887-3896.

Lancaster, P.A., Carstens, G.E., Crews, D.H. \& Woods, S.A., 2005. Evaluation of feed efficiency traits in growing bulls and relationships with feeding behavior and ultrasound carcass estimates. Proc. West. Sect. Am. Soc. Anim. Sci. 56, 461-464.

Naik, M., 2007. Identification and characterization of genetic markers and metabolic pathways controlling net feed efficiency in beef cattle. PhD thesis, University of Adelaide University, Australia.

Nelson, D.L. \& Cox, M.M., 2008. Lehninger Principles of Biochemistry. 5th ed. W.H. Freeman and Company, New York.

Nkrumah, J.D., Okine, E.K., Mathison, G.W., Schmid, K., Li, C., Basarab, J.A., Price, M.A., Wang, Z. \& Moore, S.S., 2006. Relationships of feedlot feed efficiency, performance, and feeding behavior with metabolic rate, methane production, and energy partitioning in beef cattle. J. Anim. Sci. 84, 145-153.

Oddy, V.H. \& Herd, R.M., 2001. Potential mechanisms for variation in efficiency of feed utilization in ruminants. In: Proc. Feed Efficiency Workshop. Univ. New England, Australia. pp. 30-34.

Ojano-Dirain, C.P., Pumford, N.R., Toyomizu, M. \& Bottje, W.G., 2007. Association of mitochondrial function and feed efficiency. Jpn. Poult. Sci, 44, 221-237.

Richardson, E.C. \& Herd. R.M., 2004. Biological basis for variation in residual feed intake in beef cattle. 2. Synthesis of results following divergent selection. Aust. J. Exp. Agric. 44, 431-440.

Richardson, E.C., Herd, R.M., Archer, J.A. \& Arthur, P.F., 2004. Metabolic differences in Angus steers divergently selected for residual feed intake. Aust. J. Exp. Agric. 44, 441-452. 